
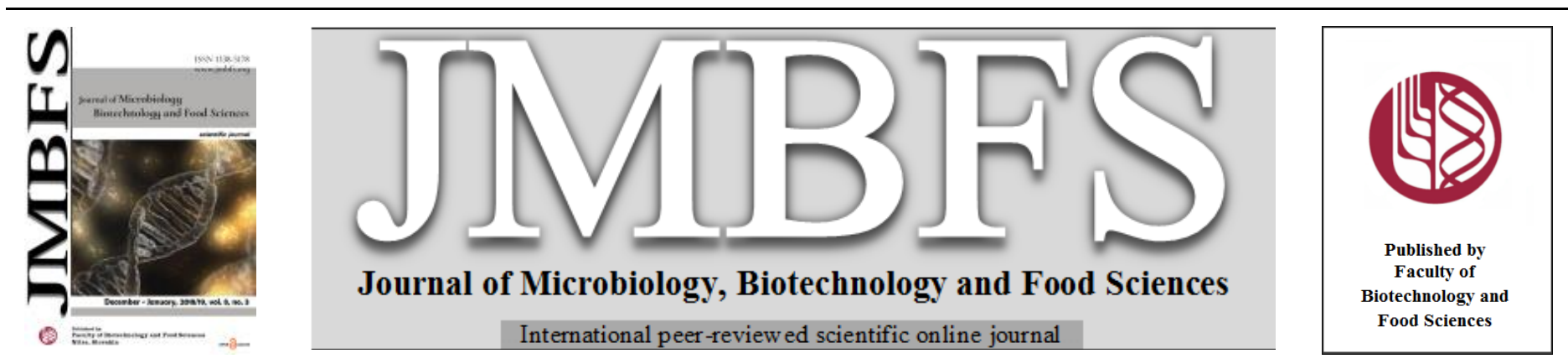

\title{
NANOTECHNOLOGY ENROLMENT IN FOOD AND FOOD SAFETY
}

\author{
Sachin K. Sonawane, Sonal P. Patil, Shalini S. Arya*
}

$\operatorname{Address(es):~}$

Food Engineering and Technology Department, Institute of Chemical Technology, Nathalal Parekh Marg, Matunga, Mumbai- 400 019, India.

*Corresponding author: ss.arya@ictmumbai.edu.in

doi: 10.15414/jmbfs.2018-19.8.3.893-900

ARTICLE INFO

Received 30. 3. 2018

Revised 21. 9. 2018

Accepted 25. 9. 2018

Published 1. 12. 2018

Review

open 2 Access

\begin{abstract}
Nanotechnology, today, characterizes medicine and food industry. It covers various aspects of food sector like fermentation, neutraceuticals but a greater influence has been observed in the sector of food safety. Nanoemulsions are being used in various fortification purposes such as calcium and rice bran oil. Nanotechnology has been extensively applied in transport vehicles using proteins and lipids to deliver bioactive nutrients. Various other sectors have been covered by this technology such as reinforcement and membrane formation processes which explores packaging area. It has also been found functional in the detection o toxic chemicals, heavy metals, pesticides and drug residues from food products. The present review articles focuses on the different areas of food sectors employing nanotechnology with its wide applications.
\end{abstract}

Keywords: Nanocoating, Nanoemulsion, nano filter aid, nanopackaging

\section{INTRODUCTION}

This century is characterized as an era of nano-science and nanotechnology which includes medicine and the food industry. Nanotechnology is the science in which the matter is manipulated with atleast one dimension sized from 1-100 nanometers with novel properties. Various nano-scale devices found in market are manufactured on a regular basis with concern to emulate the nano devices that already exists in nature for example proteins, DNA, and other natura biomolecules (German et al., 2006; Sanguansri \& Augustin, 2006). Nano science and nanotechnology has covered a broad spectrum applied in pharmaceuticals but with limited applications in the food sector (Sozer \& Kokini, 2009). This makes it essential for researchers to augment its utilization in these areas.

A several research groups (including governmental and private sector) are with the aim of exploring nanotechnology in the area of various food and agriculture sectors. Delivery of nutrients, and nutraceuticals are emergent topics to nanotechnology come under the spectrum of food and agriculture (Sozer \& Kokini, 2009).

Food safety is utmost important for good nutrition and health and is vital for sustainable development. It plays an important role in public health and eventually to society as a whole. Foodborne illness associated with food contaminants, toxins and pathogens poses a serious health threat all over the world. The presence of adulterants, food born pathogenic bacteria, toxins, antinutritional factors, persistent organic pollutants renders food unsafe for human consumption. Thus, arises a need to uncover the difference between safe and unsafe food. There have been numerous reports on role of nanomaterials in detection of toxins (Sonawane et al., 2014).

Till date, various applications of nanotechnology have been successfully carried out in various areas. The electronics, medicine and automation sectors are mostly focused by the nanotechnology. It is possible to adapt report from these sectors to be utilized in the development of food preservation as well as protection http://www.merid.org/nano/waterpaper/). In this review, the features of nanotechnology especially focusing on role related to food and different areas of food sector has been discussed.

\section{NANTOTECHNOLOGY ENROLMENT IN FOOD PROCESSING}

\section{Fermentation}

Technologies those are innovative and sustainable are expensive. Great interest have been developed by scientist to devise such technologies in the area of food technologies using cheap, and novel sources that are naturally occurring in the environment. Lignocellulosic substrate is one such example involves rice husk and sawdust which are major leftover of agricultural industry in many parts of the world.

These cellulose matryyix can be converted to a tubular structure by a simple alkaline treatment which removes lignin from it. Tubular cellulose (TC) is characterized by porous surface. These pores are nano/micro scaled in size and is highly advantageous in bioprocessing industry. TC has shown to act as a promoter of fermentation. It reduces the activation energy, facilitates nutrient followed by entrapping microbes.

Advanced use of TC was reported by Servetas et al. (2013) in the process of alcoholic/malolactic fermentation with the addition of pre -gelatinized starch while Kumar et al., (2014) also employed it for lactic acid production with the help of polylactic acid. Kumar et al., (2016) produced TC from delignification of mango (Magniferaindica L.), sal (Shorearobusta G.) saw dust and rice husk (Oryza sativa L.) and used in various food bioprocesses (Kumar et al., 2016) The TCs was found to be useful for $S$. cerevisiae immobilization carriers in grape must and glucose media fermentation. It improved fermentation rates, ethano content, productivity, and volatiles formation. Encapsulated mixed halophile culture in nano/micro-tubular cellulose enhances ripening and maintains pickles properties (Papafotopoulou-patrinou et al., 2015).

\section{NANTOTECHNOLOGY ENROLMENT IN DAIRY TECHNOLOGY}

\section{Fortification in frozen yoghurt}

Nano-emulsions are characterized by their functional efficiency and are of substantial importance in food processing. Many researchers have mixed nano emulsions with foods. Alfaro et al., (2015) while working on frozen yoghurt found that nano-emulsions of purple rice bran-oil (NPRBO) improved physicochemical properties of frozen yoghurt significantly alongwith increased viability of lactic cultures. The oil was rich in natural antioxidants like tocopherols and oryzanol(Alfaro et al., 2015).

\section{Reduction of milk fouling by using nanocoatings}

Fouling and cleaning of the equipment thereafter accounts for major of the production cost in the dairy industry (Bansal \& Chen, 2006). Plate heat exchangers usually causes fouling while milk processing. Kananeh et al., (2010) reduced this problem with the help of nano-composites coatings (Kananeh $\boldsymbol{e t}$ al. 2010). Commercially available polymer matrices were employed for the production of these coatings with hydrophobic and oleo phobic effectiveness. These coatings had following advantages, 
- low surface energy

- low roughness,

- $\quad$ simplified cleaning processes,

- $\quad$ reduced resource and chemical requirements, and

- $\quad$ increased productivity, quality and consistency.

\section{Preservation of milk by using Thymus capitatus nanoemulsion essential oil}

Essential oils are known as effective bio preservative could be added in small quantity and may retard the bacterial contamination (Selim, 2011). Milk and dairy products are consumed regularly and essential part of diet. Stored pasteurized milk and age gelation of UHT (Ultra High Temperature) milk are spoiled due to enzymatic protein degradation that is proteolyasis which affects nutritional and technological aspects (Cattaneo et al., 2014). Nanoemulsion of essential oil Thymus capitatus stop chain reaction of oxidation due to antioxidan effect of oil which donate the hydrogen atom to lipid radicles. Jemaa $\boldsymbol{e t}$ al. (2017) reported that nanoencapsulated $T$. capitatus essential oil preserve milk quality and can extend its shelf life(Ben et al., 2017).

\section{NANTOTECHNOLOGY ENROLMENT IN SEAFOODS}

\section{Calcium fortification using nano fish bone}

Wu et al., (2012) and Xie, Yin, Zhang, Zhao (2014) found that reduction in particle size to nano level have many beneficial effects in case of fish bone powder. Malde et al. (2010) have stated about the higher levels of bioavailable calcium in this fish bone. Hence, many studies have been conducted to ensure its use in variety of value added products (Jeyasanta \& Aiyamperumal, 2013; Yin et al., 2014; Jeong et al., 2013). Nano scaled particles of fish bone have exhibited better gel texture as compared to micro fish bone while the preparation of surimi gel (Yin et al., 2014). The nano inorganic calcium is highly safe and highly bio available compared to the micro one(Jeong $\boldsymbol{e t}$ al., 2013). These nano fish bones can be used as potential additive to enrich (calcium) beverages withou any sacrifice in quality as this size reduction to nanoscale removes grittiness along with increase in suspension stability. However, for the production of nano fish bone is tedious and requires use of special processing technology. A robust technique called High-energy wet media milling was introduced by Yin and Park (2014).

\section{Improvement of gelation in surim}

An essential step that results in formation of desired texture in surimi based products is gelation of protein which is supposed to be induced by endogenous transglutaminase (TGase). Addition of calcium compounds to surimi pastes enhances the surimi texture as the activity of this endogenous TGase depends on calcium. Additionally, calcium augments hydrophobic interactions leading to textural improvement by destroying myosin structures. Yin and Park (2014) suggested use of fish bone as a functional ingredient in surimi products due to its rich calcium content. They observed large particles to be ineffectual as they disconnect protein-protein gel networks and found nano sized fish bones (NFB) to increase the activity of endogenous transglutaminase (TGase) in Alaska Pollock surimi along with increasing intensity of myosin heavy chain cross links and eventually gelation. NFB allows them to be imbedded into fish myofibrillar protein gel networks without sacrificing gelling ability.

\section{Fortification of nano encapsulated fish oil}

Fish oil has also been nano-encapsulated with the help of nano-liposome. This encapsulated fish oil was found to be useful in fortifying yogurt. The yogurt had low acidity, syneresis and peroxide value. Ghorbanzade et al., (2017) have reported enhanced levels of DHA and EPA in yogurt when fortified with nanoencapsulated fish oil.

\section{NANTOTECHNOLOGY ENROLMENT IN CEREALS}

\section{Inhibition of starch retrogradation}

Starch when cooked undergoes retrogradation during storage which produces undesirable changes in its properties. The ratio of amylose to amylopectin causes starch to retrograde. There are two categories of starch retrogradation viz., short term retrogradation andlong-term retrogradation as explained by $\mathbf{X u}$ et $\boldsymbol{a l}$. (2012). Amylose fraction accounts for the short-term development of retrogradation or crystallization and long term retrogradation occurs due to the amylopectin fraction ( Chang $\boldsymbol{\&}$ Lin 2007).

Ji et al., (2017) introduced Chitin nano-whiskers (CNW) as an inhibitor of retrogradation of starch. CNW are prepared from different chitin sources (Sriupayo et al., 2005). They are employed for various purposes in many industries including food, drug, polymer. Ji et al., (2017) explained inhibition of retrogradation in maize and potato starches and the changes occurring alongwith due to addition of CNWs.

\section{ENROLMENT OF NANOTECHNOLOGY IN EMULSION}

Nanoemulsions differ from conventional emulsions with respect to particle dimensions and surface area. It thus increases contact between nanoemulsion and pro-oxidants (Yi et al., 2014). Huang et al., (2010) and McClements \& Rao (2011) found that smaller diameter, flocculation stability, optical clarity and bioavailability of nano emulsions are of great advantages in many applications. Huang et al., (2010) have stated about the required antioxidant capacity in emulsions. Oil-in-water nanoemulsions having $10 \mathrm{~mm}$ of particle radiusare delivery systems those protect lipophilic nutraceuticals to undergo degradation and oxidation. Yi et al., (2016) found enhanced $\beta$-carotene retention with the help of $\alpha$-lactalbumin (ALA)-catechin conjugates. They found that these conjugates were very innovative to be used in functional food and proved their potential application in nanodelivery systems to improve the stability of bioactive molecules.

A continuous method for production of finely dispersed oil in water nanoemulsion was reported by Katagi et al., (2007). They prepared a coarse emulsion at low levels of surfactant concentration. Conventional homogenization process was employed under subcritical water concentrations. They found that a fine emulsion could be prepared with oil droplets of $40 \mathrm{~nm}$ diameter and an arrow distribution at the ratio of weights of surfactant to oil of 0.35 or higher.

Kreuter (2007), Singh \& Lillard (2009) reported about the huge interest of nano emulsion or nano-encapsulation of bioactive molecules as it increases the bioavailability of drugs and nutrients when consumed. This technique though nonspecific, has shown to be more effective on microscale to increase bioavailability ( Lipinski et al., 2012). This technique will be the efficient one as surface area to mass ratio along with rate of uptake increases in case of nanoscale (De Jong \& Borm, 2008). Mechanical processing is usually employed for the formation of nanoemulsions and nanoparticles. Some of the common techniques involves the use of ultrasound (Jafari et al., 2007; Mahdi Jafari et al., 2006), high pressure homogenization (Liu et al., 2009), and micro-fluidization (Jafari et al., 2007; Mahdi Jafari et al., 2006). This strategy is helpful in the food sector which involves the integration of various ingredients including polyphenols, enzymes and others for their stabilization, protection and preservation during the processing environment (Zuidam, 2010).

Cheuk et al., (2015) used octenyl succinate esterified starch and rice bran oil for encapsulation of coenzyme $\mathrm{Q}_{10}$. It was further freeze dried and stored. Upon reconstitution, the resulting coenzyme emulsion was visibly stable. The nano encapsulation was found to be very effective. They showed that the coenzyme formulation enhaced nutritional value of fruit juices, and in increasing coenzyme levels in baked goods.

\section{ENROLMENT ON NANOTECHNOLOGY IN IMMOBILIZATION}

Now-a-days, there is an increasing attention for membrane-immobilized enzymes in a various biotechnological field such as biosensors. Aghababaie, Beheshti, and Razmjou (2016) discovered a membrane which have covalent bonding of lipase. This membrane shows high activity, stability, and improved hydrophilicity. They immobilized Candida rugosa lipase (CRL) covalently on nanocomposite membrane. Hydrothermal process was employed for the preparation of the novel $\mathrm{Fe}_{3} \mathrm{O}_{4} @ \mathrm{SiO}_{2}$ dip-coated membrane at low temperature and 3-aminopropyletriethoxysilane (APTES) and glutaraldehyde. These was used to functionalize the nanocomposite membrane for lipase immobilization. The active aldehyde groups and hydrophilic properties are reasponsible to improved the realative activity and loading capacity of nanocomposite membrane which provided a suitable surface for lipase and pectinase immobilization (Ladole $\boldsymbol{e t}$ al., 2014).

Enzyme immobilization on nanocomposite membranes is acquiring interest these days due to the beneficial effects of nanoparticles in combination with membrane filtration. Previously, laccase was immobilized on $\mathrm{TiO}_{2}$ functionalized membrane by Hou et al., (2014) for the purpose of membrane bioreactor. The main component of the membrane involves inorganic particles which are characterized by properties of organic as well as inorganic components (Hou et al., 2014b). Additionally, studies have been carried out with different nanoparticles by Razmjou, Mansouri, and Chen (2011)

Nanostructured metaloxides (NMOs) is another recommended by Tenne $\boldsymbol{e} t \boldsymbol{a}$.l., (2008) mode that is employed for immobilization with an effective surface, orientation, structural modification, and biological activity and consequently, improved sensing characteristics. Khan, Husain, and Azam (2012) have successfully immobilized $\alpha$-Amylase onto ferric oxide nanoparticles by the mechanism of simple adsorption and they found it to convert starch effectively in industrial continuous reactors. The kinetic and thermodynamic parameters of enzymes are predominenetly enhanced after immobilization, as the cross linking agents used either gluteraldehyde or polysaccharides led to changes structural conformation of enzymes (Muley et al., 2017). The thermal denaturation of enzymes at elevated temperature is prevented due to macromolecular crowding and formation of new covalent and non-covalent linkages within cross linking agents like gluteraldehyde and polysaccharides. The higher thermal and storage stability was found in polymer-grafted nanoparticle (Zhang and Sun, 2018) 
Coenzyme $\mathrm{Q}_{10}\left(\mathrm{CoQ}_{10}\right)$ acts as a carrier of electrons in the respiratory chain of mitochondria.It generates energy using carbohydrates and fatty acids through metabolic pathway. It also has other beneficial functions in the body. In a healthy young individual, biosynthesis of $\mathrm{CoQ}_{10}$ occurs naturally but tendancy decreases gradually with increasing age which leads to the need of oral supplementation As stated before, nanoparticles provide better stability due to smaller particle size which increases dissolution rate of drugs ( Rasenack \& Muller 2002). Kim $\boldsymbol{e}$ al., (2012) prepared aqueous dispersion of $\mathrm{CoQ}_{10}$ nano particles using amylo maize by simple physical blending without addition of any emulsifier. It was found that a storage stable homogenous dispersion of CoQ10 can be reproduced by centrifugation from its aqueous starch dispersion (Kim et al., 2012).

\section{NANOTECHNOLOGY ENROLMENT IN NEUTRACEUTICAL}

Nano carriers are material those are employed as transport modules and encounter various barriers in the route to their target. Micelles, polymers, carbonbased materials and liposomes are some of the commonly used nano vehicles.

\section{Proteins as nano vehicles}

Food proteins are the most adapted biopolymers employed conventionally for various transport platforms for the purpose of delivery of numerous bioactive substances hydrophobic in nature (Israeli-Lev and Livney, 2014; Wan et al. 2015). Advances in such food-grade colloidal delivery vehicles are gaining importance ever since last few years in order to improve their dispersibility, stability and bioavailability of nutrients. Jiang et al., (2014); Wang et al., (2015) and Wu et al., (2014) reported delivery system with protein hydrolysates (anchovy muscle protein hydrolysate for non-heme iron, zein hydrolysate for curcumin, and silver carp protein hydrolysate for zinc. Indeed, bioactive compounds can be delivered efficiently by protein hydrolysates. Lin $\boldsymbol{e t}$ al. (2016) prepared nanocomplexes by using corn protein hydrolysate \& vitamin $D_{3}$ $\left(\mathrm{CPH}-\mathrm{VD}_{3}\right)$. These nanocommplexes have salt stability. Nanoscale formation of complexes was based on the complexation of $\mathrm{CPH}$ and VitD3 which was driven by hydrogen bonding. This complexation improved photochemical stability and in vitro bioaccessibility of $\mathrm{VitD}_{3}$ as compared with free vit $\mathrm{D}_{3}$ (Lin et al., 2016). Beta casein $(\mathrm{B}-\mathrm{CN})$ is known as an amphiphilic self-assembling protein. When in aqueous solution, minute oblate micelles with a diameter of approximately $13 \mathrm{~nm}$ of B-CN are formed in aqueous solutions. Esmaili et al., (2011) developed Betacasein (B-CN) as nano vehicle to help in enhancement of the curcumin solubility which is poorly soluble in water hence possess limited bioavailability. Esmaili $\boldsymbol{e}$ al., (2011) found that interaction between camel B-CN micelles and curcumin takes place via hydrophobic interactions resulting in increased solubility, bioavailability and antioxidant activity of curcumin.

\section{Lipid nano carriers}

Sagalowicz and Leser (2010) have highlighted various types of lipid based delivery systems for lipophilic molecules. Amongst all these, solid lipid nanoparticles (SLNs) are produced from those lipids which have solid properties at room and body temperature. The nanostructured lipid carriers (NLC) can be produce by enhancing the properties of theses SLNs by interchanging solid lipids with liquid lipids leading to formation of nano-emulsion. Aditya et al., (2014) reported the difference in composition of each delivery system on nanocarrier formation with biological activity of quercetin. They found NLC ( $\sim 34$ and 47 $\mathrm{nm}$ ) and lipid nanoemulsions (LNE) $(\sim 82$ and $83 \mathrm{~nm})$ showed maximum bioaccessibility followed by $\operatorname{SLN}(\sim 103$ and $127 \mathrm{~nm})$. They stated the possibility of fabrication of lipid nanocarriers with desires properties with the help of optimal control on the lipid physical state and composition (Aditya et al., 2014).

\section{ENROLMENT OF NANOTECHNOLGY IN FOOD PRESERVATION}

Main aim of food preservation is to prevent the growth microbial flora and other processes that bring about any undesirable changes in food and spoils it. Various methods of food preservation are available. Preservation ensures that the nutritive and sensory quality of food remains unchanged.

Various nano metals have received considerable interest in the area of food preservation. Li et al., (2011) have discussed the $\mathrm{ZnO}$ under UV irradiation initiates hydrogen peroxide $\left(\mathrm{H}_{2} \mathrm{O}_{2}\right)$ from its surface. $\mathrm{ZnO}$ falls under the category of generally recognized as safe (GRAS) material by FDA. This could be added into powdered drinks and in cakes and biscuit. The combined non thermal treatment of UV irradiation and nano- $\mathrm{ZnO}$ was effective in terms of controlling microorganisms.

\section{Photocatalytic disinfection of spoilage bacteria}

The spoilage in chicken carcass due to the gram negative bacteria (Pseudomonas fluorescens) (Liao \& Blackburn, 2006). It produces strong smell when the population reaches $\sim 10^{8} \mathrm{CFU} / \mathrm{ml}$ (Pooni and Mead, 1984). Macrococcus caseolyticus ( $M$. caseolyticus) is a gram positive bacteria spoiled meat and chicken at refrigerated temperature (Hinton et al., 2004). These bacteria are liable for fermentation and spoilage of meat and meat products (Cocolin and Ercolini, 2008).

Many studies studies have shown the disinfection ability of $\mathrm{TiO}_{2}$ (Wang et al. 2014). Wang et al., (2014) evaluated nano- $\mathrm{TiO}_{2}$ for disinfectant activity on $P$. fluorescens $(\mathrm{G})$ and $M$. caseolyticus $(\mathrm{Gp})$. They reported nano- $\mathrm{TiO}_{2}$ to increase $\mathrm{K}^{+}$releases from bacterial cells and malondialdehyde (an indicator for lipid oxidation) formation in bacterial cells, damaged cell outer boundaries, and lysed cells.

According to them, the photocatalytic disinfection of bacterial cells by nano$\mathrm{TiO} 2$ under UVA light was followed by three steps

1. Attachment of nano- $\mathrm{TiO}_{2}$ to bacterial cell surfaces

2. Impairment of cell walls and cell membranes of bacterial cells resulting in leakage of cytoplasm

3. Lysis and death of bacterial cells

\section{Synergistic antimicrobial action of nano-micelles loaded with nisin $\mathrm{Z}$ against} Staphylococcus aureus

Attention has been given these days to fabricate nano carriers with the encapsulated agents so as to get synergistic effects. For example, monolaurin along with nisin is effective to inhibit the growth of bacteria in almost similar way as explained by Christ et al., (2007), nisin blocks the synthesis of cell wall and helps formation of micro-pores in the cytoplasmic membrane and hinders pathogenic bacteria.

In the same way, monolaurin and other monoglycerides are responsible for the pore formation in the cell membrane, reported by Luo et al., (2014). Another example of such synergistic systems includes the lacto peroxidase system and monolaurin combination system which sufficiently hindered the growth of $E$. coli O157:H7 and Staphylococcus aureus (McLay et al., 2002). Zhang et al., (2009) found the combination of monolaurin and sodium dehydroacetate or ethylene diamine tetra acetic acid was effective against $E$. coli and $B$ subtilis but not $S$. aureus . According to Mansour and Milliere (2001) nisin in combination with monolaurin in free form synergistically work effectively inhibit Bacillus cereus, Bacillus coagulans, B. subtilis and Bacillus licheniformis. Sadiq et al., (2016) encapsulate nisin in manolaurin nanoparticles to inhibit bacterial load ( $S$. aureus) in food. It improved the stability of nisin loaded with MNPs which remained active for longer time against $S$. aureus.

\section{Anti microbial membranes}

Wang et al., (2012) have developed nanofibrous membrane from a composite of chitosan and nano $\mathrm{ZnO}$ with the help of electro spinning technique. Electro spinning is a process of applying high voltage to charge the fluid in order to counteract the surface tension on its surface so as to stretch the droplet. At one particular point (Taylor cone) formation of a charged liquid jet takes place due to eruption of a stream of liquid from the surface. The ohmic flow changes to convective with the migration of charge to the fiber surface. As a result, the jet elongates as a result of electrostatic repulsion and bends until it deposits on the collector and fibers with uniform nanoscaled diameter as formed.

Wang et al., (2012) combined chitosan with nano-ZnO and polyvinyl alcohol was used as a support and electrospun for the development of amalgamated nanofibres. He observed a significant increase in the antimicrobial properties on EGFP (enhanced green fluroscent protein) recombinant E. coli and C. albicans The study enlightens on the techniques of development of antimicrobial materials having the property of membrane forming and the use of such membranes will be effective in improving food safety and shelf life. As illustrated, PVA doesn't have any antimicrobial activity but it helps enhance the absorption ability of NFM surface and increases the contact between chitosan/nano- $\mathrm{ZnO}$ and microbial cells. Chitosan, nano-ZnO ions are accumulated and adhered to microbial cell membrane surface due to electrostatic attraction. It results in protein denaturation and permeability changes in membrane consequently destruction of microbial cell membrane structure also, reactive oxygen species (ROS) produced by $\mathrm{ZnO}$ nanoparticles brings about intercellular contents leakage and disrupts the microbial cell membrane. As nanoparticles move across the membrane nano- $\mathrm{ZnO}$ disrupts protein and DNA function by interfering intercellular metabolism. Conversely, the penetrated chitosan tie intracellular DNA and RNA molecules and hinders the replication of genome. This method helps in scrutinizing of antimicrobial agents against foodborne pathogens.

There are two methods used for preparation of nano composite membrane suggested by Razmjou, Mansouri, and Chen (2011).

(i) blending

(ii) coating

Dip-coating is a general technique for creation of film. It involves three steps

(1) Immersion

(2) Withdrawal

(3) Evaporation

Dip-coating leads to generation of a nano composite coating at low temperature which modifies properties of the polymeric structure like chemistry, hierarchical structure, and hydrophilicity. Most of the studies involve use of blending for the 
purpose. However, this technique fails to provide enough nanoparticles on the surface ( due to less active site) for enzyme immobilization.

Nano-silver, now-a-days is substantially catching attention as it has desirable physicochemical properties although it is well characterized by its toxicity. Sond and Salopek-Sondi, 2004 have reported its proven potential as an antimicrobia material. Almost 150 types of microorganisms cannot withstand to NS (Sond and Salopek-Sondi, 2004). These particles penetrate into microbe as the get attached to cell membrane leading to cell death. Rai, Yadav, and Gade, (2009) have explained the release of silver ions $\left(\mathrm{Ag}^{+}\right)$inside the bacterial cells augmenting its bactericidal activity. Antimicrobial and ethylene inhibition activity of NS are also reported by Kim et al., (2005). Jiang, Feng, and Wang, (2013) applied novel alginate/nano-Ag coating to shiitake mushroom and found it to be effective with improved qualities of the mushroom during the extended storage.

Preservation of fruit juices by using nisin-loaded chitosan-monomethy fumaric acid nanoparticles

Khan et al., (2018) loaded nisin in chitosan-monomethyl fumaric acid (CM-N) to develop antibacterial nanoparticles which act as novel food additatives in the preservation of fruit juices. Theses nanoparticles are effective against the food born pathogens. The significant reduction in the bacterial count was observed by employing the CM-N antimicrobial agent in the oranges juices (Khan $\boldsymbol{e t}$ al., 2018)

\section{ENROLMENT OF NANOTECHNOLOGY IN PACKAGING AND BIODEGRADABLE FILMS}

Li et al., (2009) developed a novel nano packing material by merging differen with nano powder like nano-Ag, kaolin, anatase $\mathrm{TiO}_{2}$, and rutile $\mathrm{TiO}_{2}$ with polyethylene to improve the shelf life of Chinese jujube fruit at room temperature storage. The material was found to be superior in barrier and mechanical properties. They stated such materials to be advantageous in terms of simple processing and industrial feasibility. The barrier and mechanical properties of semolina films amended with incorporation of nanokaolin indicating the potential application in food-product packaging. Kumar et al developed biodegradable nanocmposite by using chitosan/ gelatin in which active ingradient is incorporated i.e silver nanoparticle which extend the shelf life of red grape for additional two weeks as compared to hybrid film (Kumar et al., 2018)

Several researchers have reported use of metals in nanocomposite packaging materials ; . Li et al., (2017) have developed an antimicrobial nano-silver packaging film (ANP). They used a blend of polyethylene and highly dispersed $\mathrm{Ag} / \mathrm{TiO}_{2}$ for the synthesis. ANP was employed to inhibit the growth of Aspergillus flavus which produces mycotoxins on rice (Park et al., 2005) when stored at $37^{\circ} \mathrm{C}$ and $70 \%$ relative humidity. It was observed that A. flavusis inhibited due to migration of small amount of silver from ANP which reduces the mold growth during storage. ANP has found to be a potential tool in hindering the rice aging process where undesirable physicochemical changes and mold growth occur during environmental storage. As reported by Li et al., (2017), the slower aging processes efficiently delayed changes in the qualities of pasting and texture consequently maintaining the rice quality with extended shelf life.

Nanomaterial's packing is found to be beneficial for fresh-cut processing of fruits and vegetables. Nano- $\mathrm{CaCO}_{3}$-based low density polyethylene (nano- $\mathrm{CaCO}_{3}$ LDPE) is best example for this (Luo et al., 2015). This packing materia significantly hindered bacterial, yeast and mold growth in fresh cut Chinese yam. Enzyme activities leading to undesirable changes were also reduced and maintained overall visual quality (OVQ) of fruit. Its inhibit browning and maintaining quality of fresh-cut Chinese yam.These indicated that nano-CaCO3 LDPE packaging would be a promising approach in maintaining quality of freshcut fruits and vegetables.

\section{Biodegradable nano composite films}

Today is the era of biodegradable packaging due to the challenging disposal of plastic films. These are well liked alternative to plastic films. The films made with casein possess good tensile and barrier properties reported by Ghosh, Ali, and Dias (2009) and Dangaran, Cooke, and Tomasula (2006). Bora and Mishra (2016) have reported an enhancement in the various properties (mechanical, barrier, physical and antimicrobial properties) of the casein film when it developed as casein-silver conjugated nanocomposite (in outer layer) and casein nanoparticle (in casein layer). The edible bilayer pouch was developed by using heat sealable casein layer laminated with sodium alginate-pectin. The inne casein layer of the film contained casein nanoparticles while outer layer (sodium alginate-pectin) was incorporated with casein-silver conjugated nano composite. They also studied \% haemolysis which was well below the safe level and hence recorded these films to be safe for red blood cells.

Avella et al., (2005) stated nano composites to be a promising option if used with biodegradable films. Cyras et al. (2008) have shown to improve the properties of biodegradable films if incorporated with inorganic, natural fibers with polymers to create nano composites. Polymer-clay nanocomposites are the latest stages of polymer technology cost of which is an issue in its application. Almasi, Ghanbarzadeh, and Entezami (2010) have found and economical way by means of Montmorillonite (MMT) which is a nano scale clay, environment friendly and easily accessible in large amounts. It is clay of hydrated alumina silicate which consists of 10 Åthilayers having a sandwich of two tetrahedral silica sheets contained with an octahedral alumina sheet within them. Cyras $\boldsymbol{e}$ al., (2008) and Xu, Ren, and Hanna (2006) found them suitable for reinforcement purposes due to high surface area and large aspect ratio. MMT in small amounts improves properties of kefir biopolymer and whey protein isolates (WPI).

Kefiran, a microbial water soluble polysaccharide, is obtained from kefir grains and is rich in glucose and galactose. It is characterized due to viscoelastic, texturizing and gelling properties (Ghasemlou et al., 2011). Cevikbas $\boldsymbol{e t}$ al. (1994) have reported its better antibacterial, antifungal and antitumor properties with respect to other polysaccharides.

Ghasemlou et al., have shown kefiran to be a promising one as an edible film. Zolfi and Khodaiyan (2014) developed nanocomposite film consisting of kefiran-whey protein isolate (WPI) and MMT. This incorporation improved mechanical aspects of kefiran-WPI films. They found increased tensile strength and Young's modulus and reduction in percentage of elongation at break with MMT content. Also, a decrease in moisture content, moisture absorption and water solubility was observed with increasing MMT concentration. Glass transition temperature for kefiran-WPI film was $-12.5^{\circ} \mathrm{C}$. Intercalation and an exfoliated structure were seen with additions of MMT

\section{Novel nano-biocomposite antioxidant films}

Hughes et al., (2012) reported about poly (lactic acid) (PLA); thermoplastic polyester, renewable resources, highly transparent and rigid material and promising candidate for the fabrication. Thymol is effective antioxidant which retard the lipid oxidation. These poly (lactic acid) (PLA) when prepared with modified montmorillonite (D43B) were added by thymol and modified its properties (Ramos et al., 2012). D43B helps in the enhancement of mecahanical properties and reduction of oxygen transmission rate by the formation of intercalated structures. The modification of the elastic modulus, elongation at break and polymer plasticization due to the addition of thymol which decreased the PLA glass transition temperature. The enlargement in the nano composites carried out with addition of PLA with nanoclays or active additives (Hwang $\boldsymbol{e}$ al., 2012), and nanofillers in biopolymer matrices could be used for food packaging application. It helps to enhance mechanical and gas barrier properties and extend the shelf life. Sahraee et al., (2017) developed biodegradable polymers with addition of chitin nano fibers (N-chitin) in gelatin based nanocomposite film which improved water vapor barrier properties. Savvashe, Kadam, and Mhaske (2015) utilize nano-alumina in nano-composite films as a potential reinforcing agent for guar gum to improve its performance properties. Polypropylene (PP) is chemically inert and one of the versatile range of polymers plastic that can be processed in many ways and has many applications in food packaging (Kirwan et al., 2011). Manikantan and Varadharaju (2011) studied the storage stability of banana chips in developed polypropylene (PP) based nanocomposite food packaging films at ambient room temperature. They observed better stability of measured quality characteristics of banana chips when packed in polypropylene (PP) based nanocomposite than any other treatment and also ascertained at applicability in high value food products.

\section{Biodegradable film for light sensitive food products}

One of the greatest attentions of the food industry is prevention of food spoilage from oxidation due to light . Edible films for example, protein- polysaccharidebased films possess good mechanical and barriers properties but still lacks barrier properties necessary for protection from UV light. Hence fail in prevention of lipid photo oxidation. In recent years, concern has been given to incorporate these nano particles into biodegradable biopolymer-based films so as to enhance their mechanical and barrier properties (Abdollahi et al., 2013).

Li et al., (2011) have improved functional and antimicrobial properties of biodegradable films successively with the help of metal oxides like $\mathrm{TiO}_{2}$. These are also characterized by their cost feasiblity and non-toxicity and photostable properties. Researchers have recommended its use for prevention of oxidation induced by light in food packaging systems and in the end of deterioration of food (Li et al., 2011). Vejdan et al. (2016) developed a biodegradable bilayer gelatin/agar film with incorporation of $\mathrm{TiO} 2$ by means of the solution casting method. The properties (water vapour barrier, mechanical strength, light transmission) of bilayer film were greatly influenced by $\mathrm{TiO} 2$ nanoparticle content. They proposed this film as a potential tool for preservation of lightsensitive food.

\section{MIGRATION OF NANOPARTICLES IN FOOD PACKAGING}

Engineered nano particles (ENP) though are promising tools in the current industry, its exposure may cause certain environmental problems/or harm human health. De Azeredo (2013) have stated about the necessity to understand the 
migration and possible health effects of ENPs while using them in packaging of food materials.

The major challenge in detection of ENPs in foodstuffs is determination of associated risks while their use. This is the main reason behind the negligence of data regarding intricacies in analysis of ENPs in real food matrices that relates with the migration of ENPs. Previously, only typical methods were being used to perform the assessment of mass transport process and estimation of all types of migrations in food materials. Hence, the need arises for development of techniques those will help detection of nanoparticles in real food matrices. The evaluation of toxic effects of nanoparticles must involve finding their size and tendency at which they can be released from the packaging material and migrate into food. Very few articles are available discussing the migration of ENPs into real-food matrices. Cushen et al., (2012) studied migration of such ENPs (AGNPs) occurring in chicken breasts which was affected due to storage temperatures and found the occurrence of migration at range of 0.03-8.4 $\mathrm{mgkg}^{-}{ }^{1}$. Busolo and Lagaron (2012) tried to determine migration of nanoparticles in foods packed in high-density polyolefin films (HDPF) with nano-clay. Sometimes, migration is mandatory for the desired antimicrobial activity for instance; reinforced thermoplastic polymers incorporated with Ag-NPs.

Levels of $\mathrm{Ag}^{+}$were detectable in meat exudates when meat samples were packed with Ag-NP incorporated cellulose pads. The majority of the articles highlighting migration of nanoparticles have concerned with starch or cellulose (organic nanomaterial). In a study conducted to investigate the migration from a nanopackaging material in vegetable samples, iron and magnesium were not significantly present but silicon ( $\mathrm{Si}$ ) was found to be migrated in the sample. The packaging material was obtained by technique of polymer melt processing and dispersion of ng nano-clay in different starch-based materials (Avella $\boldsymbol{e t} \boldsymbol{a l}$., 2005).

\section{ENROLEMENT OF NANOTECHNOLOGY IN FOOD SAFETY}

The great majority of people at times experience foodborne disease in their lives due to consumption of unsafe food that causes many diseases, ranging from diarrhoeal diseases to severe health problems. Hence, it is very essential to prevent food causing diseases and ensure food that we eat is safe.

Dimetridazole (DMZ, 1,2-dimethyl-5-nitroimidazole) is a veterinary drug which is banned in food producing animals due to its toxicity (Ho et al., 2005) Detection of DMZ is a complex one which requires extensive pretreatments one of which is solid phase extraction (SPE). To increase selectivity of SPE molecularly imprinted polymer (MIP) are being employed in recent years. Hu $\boldsymbol{e}$ al., (2014) developed a novel dimetridazole-magnetic molecular imprinted polymer (DMMIP) with the core-shell structure which was prepared by combination of surface imprinting technique and sol-gel method with 3aminopropyltriethoxysilane and Methyltrimethoxysilane as monomers, $\mathrm{Al} 3+$ as dopant and tetraethyl orthosilicate as crosslinker in the presence of template DMZ. They further applied this prepared nano-sorbentto the measurement of DMZ by SPE along with UV-Vis spectrophotometric detection and observed that DMMIP possesses are markable affinity for DMZ, probably owing to the enhanced Lewis acid-base interaction between the imprinted sites and the template. Thus, this is the efficient technique for suggested this as a sensitive, selective and cost-efficient method for the determining trace levels of DMZ residue in food and related products.

\section{Clenbuterol sensing}

Clenbuterol (CLB) is a beta 2 adrenergic agonist which used as growth promoter about 20 years ago and given to the domestic animals. It helps to reduce adipose content in animal meat as the lean meat rate increases in flattering process. But these remain in the liver, fur and retina of animal which is responsible for food poisoning and also include muscle tremor, tachycardia, palpitation and dizziness So its detection in terms of food safety is very important. Zhao et al, 2011 developed molecular imprinted film (MIP-CNSQ/WGE) that detects CLB. The film was based on chitosan/nano-silver/poly quercetin compound.

\section{Determination of lead}

Lead intoxication may cause neuropsychological disfunction to death Aboufazeli et al., (2013) has synthesized high surface area magnetic nanoparticles with the help of coating meso porous silica on $\mathrm{Fe}_{3} \mathrm{O}_{4}$ nano-particles which helps in tracing the lead ions in aqueous samples. Nano porous silica explored as adsorption of organic compounds and metal ions due to the high surface area and high stability.

\section{CONCLUSION}

Nanoscience technology is acquiring high application in research and development. Nanotechnology has been extensively used in the area of food processing like enhancement of fermentation, surimi gelation along with fortification and also found useful in prevention of the processes that lead to undesirable changes like milk fouling and starch retrogradation. Use of nanotechnology in membranes formation is also a milestone. Various techniques of development of antimicrobial membranes with nano materials have been enlightened. Almost 150 types of microorganisms are reported to be unable to withstand nano metals.

Nano particles are found to be suitable for reinforcement purposes due to high surface area and large aspect ratio. Nanomaterial's packing is found to be beneficial for fresh-cut processing of fruits and vegetables. However, while using ENPs in packaging it becomes crucial to understand their migration and possible health effects of such products when in contact with food materials.

Nano particles are also proven as excellent transport platforms. Nanotechnology is gaining its place in the area of food safety with the advantageous role while detection of toxic chemicals, heavy metals, pesticide and drug residues.Altogether, nano technology today is gaining a huge attention in around every sector of food industry.

Aknowledgement: We are thankful to University Grant Commission for providing funds. In this review article Sachin K Sonawane and Sonal Patil equally contributed in the construction of manuscript under the guidance of $\mathrm{Dr}$ Shalini S Arya.

\section{REFERENCES}

ABDOLLAHI, M., ALBOOFETILEH, M., REZAEI, M., BEHROOZ, R., 2013. Comparing physico-mechanical and thermal properties of alginate nanocomposite films reinforced with organic and/or inorganic nanofillers. Food Hydrocolloids, 32 (2), 416-424 https://doi.org/10.1016/j.foodhyd.2013.02.006 ABOUFAZELI, F., REZA, H., ZADEH, L., SADEGHI, O., KARIMI, M., NAJAFI, E., 2013. Novel ion imprinted polymer magnetic mesoporous silica nano-particles for selective separation and determination of lead ions in food samples. Food Chemistry, 141, 3459-3465. https://doi:10.1016/j.foodchem.2013.06.062

ADITYA, N.P., MACEDO, A.S., DOKTOROVOVA, S., SOUTO, E.B., HOON S., CHANG, P., KO, S., 2014. Development and evaluation of lipid nanocarriers for quercetin delivery: a comparative study of solid lipid nanoparticles (SLN), nanostructured lipid carriers (NLC), and lipid nanoemulsions (LNE). LWT Food Science and Technology, 59 (1), 115-121. https://doi:10.1016/j.lwt.2014.04.058

AGHABABAIE, M., BEHESHTI, M., RAZMJOU, A., 2016. Food and Bioproducts Processing Covalent immobilization of Candida rugosa lipase on a novel functionalized Fe $3 \mathrm{O} 4$ @ SiO 2 dip-coated nanocomposite membrane. Food Bioproduts and Processing, 100, 351-360. https://doi:10.1016/j.fbp.2016.07.016

ALFARO, L., HAYES, D., BOENEKE, C., XU, Z., BANKSTON, D., PETER, J., 2015. Physical properties of a frozen yogurt fortified with a nano-emulsion containing purple rice bran oil. LWT - Food Science and Technology,62 (2), 1184-1191. https://doi:10.1016/j.lwt.2015.01.055

ALMASI, H., GHANBARZADEH, B., ENTEZAMI, A.A., 2010 Physicochemical properties of starch-CMC-nanoclay biodegradable films International Journal of Biological and Macromolecules, 46 (1), 1-5 https://doi:10.1016/j.ijbiomac.2009.10.001

AVELLA, M., DE VLIEGER, J.J., ERRICO, M.E., FISCHER, S., VACCA, P., VOLPE, M.G., 2005. Biodegradable starch/clay nanocomposite films for food packaging applications. Food Chemistry, $93 \quad$ (3), 467-474 https://doi:10.1016/j.foodchem.2004.10.024

BANSAL, B., CHEN, X.D., 2006. A critical review of milk fouling in heat exchangers. Compreshive Reviews in Food Science and Food Safty https://doi:10.1111/j.1541-4337.2006.tb00080.x

BEN, M., FALLEH, H., NEVES, M.A., ISODA, H., NAKAJIMA, M., 2017 Quality preservation of deliberately contaminated milk using thyme free and nanoemulsified essential oils. Food Chemistry, 217, 726-734 https://doi:10.1016/j.foodchem.2016.09.030

BORA, A., MISHRA, P., 2016. Characterization of casein and casein-silver conjugated nanoparticle containing multifunctional (pectin???sodium alginate/casein) bilayer film. Journal of Food Science and Technology, https://doi:10.1007/s13197-016-2343-4

BUSOLO, M.A., LAGARON, J.M., 2012. Oxygen scavenging polyolefin nanocomposite films containing an iron modified kaolinite of interest in active food packaging applications. Innovative Food Science and Emerging Technology, https://doi:10.1016/j.ifset.2012.06.008

CATTANEO, S., STUKNYTE, M., PELlEGRINO, L., DE NONI, I., 2014. Targeted peptides for the quantitative evaluation of casein plasminolysis in drinking milk. Food Chemistry, https://doi:10.1016/j.foodchem.2014.01.053 CEVIKBAS, A., YEMNI, E., EZZEDENN, F.W., YARDIMICI, T. CEVIKBAS, U., STOHS, S.J., 1994. Antitumoural antibacterial and antifungal activities of kefir and kefir grain. Phytherapy Research, 8 (2), 78-82. https://doi:10.1002/ptr.2650080205

CHANG, Y.H., LIN, J.H., 2007. Effects of molecular size and structure of amylopectin on the retrogradation thermal properties of waxy rice and waxy cornstarches. Food Hydrocollids, https://doi:10.1016/j.foodhyd.2006.07.008 
CHRIST, K., WIEDEMANN, I., BAKOWSKY, U., SAHL, H.G., BENDAS, G., 2007. The role of lipid II in membrane binding of and pore formation by nisin analyzed by two combined biosensor techniques. Biochim. Biophys. Acta Biomembr. https://doi:10.1016/j.bbamem.2006.12.003

COCOLIN, L., ERCOLINI, D., 2008. Molecular techniques in the microbial ecology of fermented foods, Molecular Techniques in the Microbial Ecology of Fermented Foods. https://doi.org/10.1007/978-0-387-74520-6

CUSHEN, M., KERRY, J., MORRIS, M., CRUZ-ROMERO, M., CUMMINS, E., 2012. Nanotechnologies in the food industry - Recent developments, risks and regulation. Trends in Food Science and Technology https://doi:10.1016/j.tifs.2011.10.006

CYRAS, V.P., MANFREDI, L.B., TON-THAT, M.T., VAZQUEZ, A., 2008. Physical and mechanical properties of thermoplastic starch/montmorillonite $\begin{array}{llll}\text { nanocomposite films. } & \text { Carbohydrates } & \text { Polymer, }\end{array}$ https://doi:10.1016/j.carbpol.2007.11.014

DANGARAN, K.L., COOKE, P., TOMASUlA, P.M., 2006. The effect of protein particle size reduction on the physical properties of $\mathrm{CO} 2$-precipitated casein films. Journal of Food Science, https://doi:10.1111/j.17503841.2006.00012.x

DE AZEREDO, H.M.C., 2013. Antimicrobial nanostructures in food packaging. Trends in Food Science and Technology https://doi:10.1016/j.tifs.2012.11.006 DE JONG, W.H., BORM, P.J.A., 2008. Drug delivery and nanoparticles: Applications and hazards. International Journal of Nanomedicine https://doi:10.2147/IJN.S596

GERMAN, J.B., SMILOWITZ, J.T., ZIVKOVIC, A.M., 2006. Lipoproteins: When size really matters. Current Opinion in Colloid and Interface Science. https://doi:10.1016/j.cocis.2005.11.006

GHASEMLOU, M., KHODAIYAN, F., OROMIEHIE, A., 2011a. Physical, mechanical, barrier, and thermal properties of polyol-plasticized biodegradable edible film made from kefiran. Carbohydrates Polymer, https://doi:10.1016/j.carbpol.2010.12.010

GHASEMLOU, M., KHODAIYAN, F., OROMIEHIE, A., YARMAND, M.S., 2011B. Development and characterisation of a new biodegradable edible film made from kefiran, an exopolysaccharide obtained from kefir grains. Food Chemistry, https://doi:10.1016/j.foodchem.2011.02.003

GHASEMLOU, M., KHODAIYAN, F., OROMIEHIE, A., YARMAND, M.S., 2011c. Characterization of edible emulsified films with low affinity to water based on kefiran and oleic acid. International Journal of Biological Macromolecule. https://doi:10.1016/j.ijbiomac.2011.05.013

GHORBANZADE, T., JAFARI, S.M., AKHAVAN, S., HADAVI, R., 2017. Nano-encapsulation of fish oil in nano-liposomes and its application in fortification of yogurt. Food Chemistry, 216, 146-152. https://doi:10.1016/j.foodchem.2016.08.022

GHOSE, A.K., VISWANADHAN, V.N., WENDOLOSKI, J.J., 1999. A Knowledge-Based Approach in Designing Combinatorial or Medicinal Chemistry Libraries for Drug Discovery. 1. A Qualitative and Quantitative Characterization of Known Drug Databases. Journal of Combinatorial Chem https://doi:10.1021/cc9800071

GHOSH, A., ALI, M.A., DIAS, G.J., 2009. Effect of cross-linking on microstructure and physical performance of casein protein. Biomacromolecules https://doi:10.1021/bm801341x

NAIR,G., DUFRESNE, K., A., 2003. Crab shell chitin whisker reinforced natura rubber nanocomposites. 1. Processing and swelling behavior. Biomacromolecules, https://pubs.acs.org/doi/abs/10.1021/bm020127b

HINTON, A., CASON, J.A., INGRAM, K.D., 2004. Tracking spoilage bacteria in commercial poultry processing and refrigerated storage of poultry carcasses International Journal of Food Microbiology, http://doi:10.1016/S01681605(03)00377-5

HO, C., SIN, D.W.M., WONG, K.M., TANG, H.P.O., 2005. Determination of dimetridazole and metronidazole in poultry and porcine tissues by gas chromatography-electron capture negative ionization mass spectrometry. Analytica Chimica Acta, http://doi:10.1016/j.aca.2004.09.004

HOU, J., DONG, G., YE, Y., CHEN, V., 2014a. Laccase immobilization on titania nanoparticles and titania-functionalized membranes. The Journal of Membrane Science, http://doi:10.1016/j.memsci.2013.10.019

HOU, J., DONG, G., YE, Y., CHEN, V., 2014b. Enzymatic degradation of bisphenol-A with immobilized laccase on $\mathrm{TiO} 2$ sol-gel coated PVDF membrane. The Journal of Membrane Science, http://doi:10.1016/j.memsci.2014.06.027 HU, C., DENG, J., ZHAO, Y., XIA, L., HUANG, K., JU, S., XIAO, N., 2014. A novel core-shell magnetic nano-sorbent with surface molecularly imprinted polymer coating for the selective solid phase extraction of dimetridazole. Food Chemistry, http://doi:10.1016/j.foodchem.2014.02.143

HUANG, Q., YU, H., RU, Q., 2010. Bioavailability and delivery of nutraceuticals using nanotechnology. Journal of Food Science, 75, R50-7. http://doi:10.1111/j.1750-3841.2009.01457.x

HUGHES, J., THOMAS, R., BYUN, Y., WHITESIDE, S., 2012. Improved flexibility of thermally stable poly-lactic acid (PLA). Carbohydrates Polymere, http://doi:10.1016/j.carbpol.2011.11.078

HWANG, S.W., SHIM, J.K., SELKE, S.E., SOTO-VALDEZ, H., MATUANA, L., RUBINO, M., AURAS, R., 2012. Poly(L-lactic acid) with added a-tocopherol and resveratrol: Optical, physical, thermal and mechanical properties. Polymer International, https://doi.org/10.1002/pi.3232

ISRAELI-LEV, G., LIVNEY, Y.D., 2014. Self-assembly of hydrophobin and its co-assembly with hydrophobic nutraceuticals in aqueous solutions: Towards application as delivery systems. Food Hydrocolloids, http://doi:10.1016/j.foodhyd.2013.07.026

JAFARI, S.M., HE, Y., BHANDARI, B., 2007. Production of sub-micron emulsions by ultrasound and microfluidization techniques. Journal of Food Engineering, http://doi:10.1016/j.jfoodeng.2007.03.007

JEONG, M.S., CHO, H.S., PARK, S.J., SONG, K.S., AHN, K.S., CHO, M.H. KIM, J.S., 2013. Physico-chemical characterization-based safety evaluation of nanocalcium. Food Chemistry and Toxicology, http://doi:10.1016/j.fct.2013.08.024

JI, N., LIU, C., ZHANG, S., YU, J., XIONG, L., SUN, Q., 2017. Effects of chitin nano-whiskers on the gelatinization and retrogradation of maize and potato $\begin{array}{llll}\text { starches. } & \text { Food } & \text { Chemistry, } & \text { 214, }\end{array}$ http://doi:10.1016/j.foodchem.2016.07.113

JIANG, L., WANG, B., LI, B., WANG, C., LUO, Y., 2014. Preparation and identification of peptides and their zinc complexes with antimicrobial activities from silver carp (Hypophthalmichthys molitrix) protein hydrolysates. Food Research International. http://doi:10.1016/j.foodres.2014.06.008

KANANEH, A.B., SCHARNBECK, E., KÜCK, U.D., RÄBIGER, N., 2010. Food and Bioproducts Processing Reduction of milk fouling inside gasketed plate heat exchanger using nano-coatings. Food Bioproduct and Processing, 88, 349356. http://doi:10.1016/j.fbp.2010.09.010

KATAGI, S., KIMURA, Y., Ã, S.A., 2007. Continuous preparation of O / W nano-emulsion by the treatment of a coarse emulsion under subcritical water conditions. Lwt- Food Science and Technology, 40, 1376-1380. http://doi:10.1016/j.lwt.2006.09.004

KHAN, I., TANGO, C.N., MISKEEN, S., OH, D.H., 2018. Evaluation of nisinloaded chitosan-monomethyl fumaric acid nanoparticles as a direct food additive. Carbohydrates Polymer, http://doi:10.1016/j.carbpol.2017.11.034

KHAN, M.J., HUSAIN, Q., AZAM, A., 2012. Immobilization of porcine pancreatic $\alpha$-amylase on magnetic $\mathrm{Fe} 2 \mathrm{O} 3$ nanoparticles: Applications to the hydrolysis of starch. Biotechnological and Bioprocess Engineering. http://doi:10.1007/s12257-011-0105-8

KIM, J. H., LEE, A. K., SUH, J.K., 2005. Effect of certain pre-treatment substances on vase life and physiological characters in Lilium spp. Acta Horticulture. 673, 307-314. https://doi.org/10.17660/ActaHortic.2005.673.39

KIM, E., KIM, J., CHUNG, H., LIM, S., 2012. Preparation of aqueous dispersions of coenzyme Q 10 nanoparticles with amylomaize starch and its dextrin. LWT - Food Science and Technology 47, 493-499. https://doi.org/10.1016/j.1wt.2012.02.013

KIRWAN, M.J., PLANT, S., STRAWBRIDGE, J.W., 2011. Plastics in Food Packaging, in: Food and Beverage Packaging Technology: Second Edition. https://doi:10.1002/9781444392180.ch7

KREUTER, J., 2007. Nanoparticles - A historical perspective. International Journal of Pharmaceutics, 331, 1-10. https://doi.org/10.1016/j.ijpharm.2006.10.021

KUMAR, M. N., GIALLELI, A. I., MASSON, J. B., KANDYLIS, P. BEKATOROU, A., KOUTINAS, A. A., \& KANELLAKI, M. 2014. Lactic acid fermentation by cells immobilised on various porous cellulosic materials and their alginate/poly-lactic acid composites. Bioresource Technology, 165, 332335. http://doi.org/10.1016/j.biortech.2014.02.110

KUMAR, M.N., GIALLELI, A., BEKATOROU, A., KOUTINAS, A.A., KANELLAKI, M., 2016. Application of nano / micro-tubular cellulose of Indian origin for alcoholic fermentation and cold pasteurization of contaminated water LWT - Food Science and Technology, 69, 273-279. https://doi:10.1016/j.1wt.2016.01.040

KUMARA, S., SHUKLAA, A.,BAULA, P. P., MITRAB, A, HALDER, D. 2018. Biodegradable hybrid nanocomposites of chitosan/gelatin and silver nanoparticles for active food packaging applications. Food Packaging and Shelf Life, 16, 178-184. https://doi.org/10.1016/j.fpsl.2018.03.008

LI, H., LI, F., WANG, L., SHENG, J., XIN, Z., ZHAO, L., XIAO, H., ZHENG, Y., HU, Q., 2009. Effect of nano-packing on preservation quality of Chinese jujube. Food Chemistry, 114, 547-552. https://doi:10.1016/j.foodchem.2008.09.085

LI, L., ZHAO, C., ZHANG, Y., YAO, J., YANG, W., HU, Q., WANG, C., CAO, C., 2017. Effect of stable antimicrobial nano-silver packaging on inhibiting mildew and in storage of rice. Food Chemistry, 215, 477-482. http://doi:10.1016/j.foodchem.2016.08.013

LI, X., LI, W., JIANG, Y., DING, Y., YUN, J., TANG, Y., ZHANG, P., 2011. Effect of nano-ZnO-coated active packaging on quality of fresh-cut "Fuji" apple International Journal of Food Science and Technology, http://doi:10.1111/j.1365 2621.2011.02706.X

LIN, Y., WANG, Y.H., YANG, X.Q., GUO, J., WANG, J.M., 2016. Corn protein hydrolysate as a novel nano-vehicle: Enhanced physicochemical stability and in vitro bioaccessibility of vitamin D3. LWT - Food Science and Technology https://doi:10.1016/j.lwt.2016.05.020 
LIPINSKI, C.A., LOMBARDO, F., DOMINY, B.W., FEENEY, P.J., 2012. Experimental and computational approaches to estimate solubility and permeability in drug discovery and development settings. Advanced Drug Delivery Reviews, https://doi:10.1016/j.addr.2012.09.019

LIU, D., WU, Q., CHEN, H., CHANG, P.R., 2009. Transitional properties of starch colloid with particle size reduction from micro- to nanometer. Journal of Colloid and Interface Science, https://doi:10.1016/j.jcis.2009.07.035

LIVERSIDGE, G.G., CUNDY, K.C., 1995. Particle size reduction for improvement of oral bioavailability of hydrophobic drugs: I. Absolute oral bioavailability of nanocrystalline danazol in beagle dogs. International Journal of Pharmaceutics. https://doi:10.1016/0378-5173(95)00122-Y

LUO, C., ZENG, Z., GONG, D., ZHAO, C., LIANG, Q., ZENG, C., 2014. Evaluation of monolaurin from camphor tree seeds for controlling food spoilage fungi. Food Control. https://doi:10.1016/j.foodcont.2014.06.017

MAHDI JAFARI, S., HE, Y., BHANDARI, B., 2006. Nano-Emulsion Production by Sonication and Microfluidization-A Comparison. International Journal of Food Properties https://doi:10.1080/10942910600596464

MALDE, M.K., BÜGEL, S., KRISTENSEN, M., MALDE, K., GRAFF, I.E., PEDERSEN, J.I., 2010. Calcium from salmon and cod bone is well absorbed in young healthy men: a double-blinded randomised crossover design. Nutr. Metab. (Lond). https://doi:10.1186/1743-7075-7-61

Manikantan, M.R., Varadharaju, N., 2011. Preparation and properties of polypropylene-based nanocomposite films for food packaging. Packaging Technol and Science https://doi:10.1002/pts.925

MANSOUR, M., MILLIERE, J.B., 2001. An inhibitory synergistic effect of a nisinmonolaurin combination on Bacillus sp. vegetative cells in milk. Food Microbiology 18, 87-94. https://doi.org/10.1006/fmic.2000.0379

MCCLEMENTS, D.J., RAO, J., 2011. Food-grade nanoemulsions: formulation, fabrication, properties, performance, biological fate, and potential toxicity Critical Reviews in Food Science and Nutrition, 51, 285-330. https://doi:10.1080/10408398.2011.559558

MCLAY, J.C., KENNEDY, M.J., O'ROURKE, A.L., ELLIOT, R.M., SIMMONDS, R.S., 2002. Inhibition of bacterial foodborne pathogens by the lactoperoxidase system in combination with monolaurin. International Journal of Food Microbiology https://doi:10.1016/S0168-1605(01)00698-5

MITORAJ, D., JANCZYK, A., STRUS, M., KISCH, H., STOCHEL, G. HECZKO, P.B., 2007. Visible light inactivation of bacteria and fungi by modified titanium dioxide. Photochemical \& Photobiological Sciences, https://doi:10.1039/b617043a

MULEY, A.B., CHAUDHARI, S.A., SINGHAL, R.S., 2017. Non-covalent conjugation of cutinase from Fusarium sp. ICT SAC1 with pectin for enhanced stability: Process minutiae, kinetics, thermodynamics and structural study. International Journal of Biological Macromolecules https://doi:10.1016/j.ijbiomac.2017.04.072

PAPAFOTOPOULOU-PATRINOU, E., KALLIS, M., BEKATOROU, A. KANELLAKI, M., KOUTINAS, A.A., SCHOINA, D., TSOULOU, E., TZAVARAS, K., KOKKOROU, D., PANAS, P., 2015. Acceleration of ripening and improvement of quality of olive pickles by encapsulated cells in nano micro-tubular cellulose. LWT - Food Science and Technology, 63, 1029-1036. https://doi:10.1016/j.lwt.2015.04.009

PIERMARIA, J.A., DE LA CANAL, M.L., ABRAHAM, A.G., 2008. Gelling properties of kefiran, a food-grade polysaccharide obtained from kefir grain. Food Hydrocolloids, https://doi:10.1016/j.foodhyd.2007.10.005

PITKETHLY, M.J., 2004. Nanomaterials - the driving force. Mater. TODAY https://doi:10.1016/S1369-7021(04)00627-3

POONI, G.S., MEAD, G.C., 1984. Prospective use of temperature function integration for predicting the shelf-life of non-frozen poultry-meat products. Food Microbiology, https://doi:10.1016/0740-0020(84)90010-8

RAI, M., YADAV, A., GADE, A., 2009. Silver nanoparticles as a new generation of antimicrobials. Biotechnology Advances https://doi:10.1002/app

RAMOS, M., JIM??NEZ, A., PELTZER, M., GARRIGS, M.C., 2012 Characterization and antimicrobial activity studies of polypropylene films with carvacrol and thymol for active packaging. Journal of Food Engineering, https://doi:10.1016/j.jfoodeng.2011.10.031

RASENACK, N., MULLER, B.W., 2002. Dissolution rate enhancement by in situ micronization of poorly water-soluble drugs. Pharmaceutical Research, 19(12):1894-900

RAZMJOU, A., MANSOURI, J., CHEN, V., 2011. The effects of mechanical and chemical modification of $\mathrm{TiO} 2$ nanoparticles on the surface chemistry, structure and fouling performance of PES ultrafiltration membranes. Journal of Membrane Science https://doi:10.1016/j.memsci.2010.10.019

SADIQ, S., IMRAN, M., HABIB, H., SHABBIR, S., IHSAN, A., ZAFAR, Y., HAFEEZ, F.Y., 2016. Potential of monolaurin based food-grade nano-micelles loaded with nisin $\mathrm{Z}$ for synergistic antimicrobial action against Staphylococcus aureus. LWT - Food Science and Technology, https://doi:10.1016/j.lwt.2016.03.045

SAGALOWICZ, L., LESER, M.E., 2010. Delivery systems for liquid food products. Current Opinion in Colloid and Interface Science https://doi:10.1016/j.cocis.2009.12.003
SAHRAEE, S., MILANI, J.M., GHANBARZADEH, B., HAMISHEHKAR, H., 2017. Effect of corn oil on physical, thermal, and antifungal properties of??gelatin-based nanocomposite films containing nano chitin. LWT - Food Science and Technology https://doi:10.1016/j.1wt.2016.10.028

SALABAT, A., MIRHOSEINI, F., 2015. Applications of a new type of poly(methyl methacrylate)/TiO 2 nanocomposite as an antibacterial agent and a reducing photocatalyst. Photochemical \& Photobiological Sciences, https://doi:10.1039/C5PP00065C

SANGUANSRI, P., AUGUSTIN, M.A., 2006. Nanoscale materials development - a food industry perspective. Trends in Food Science and Technology, 17, 547556. https://doi:10.1016/j.tifs.2006.04.010

SAVVASHE, P., KADAM, P., MHASKE, S., 2015. Effect of nano-alumina concentration on the mechanical, rheological , barrier and morphological properties of guar gum. Journal of Food Science amd Technology, https://doi:10.1007/s13197-015-2114-7

SELIM, S., 2011. Antimicrobial activity of essential oils against vancomycinresistant enterococci (VRE) and escherichia coli O157: H7 in feta soft cheese and minced beef meat. Brazilian Journal of Microbiology, https://doi:10.1590/S1517-83822010005000005

SERVETAS, I., BERBEGAL, C., CAMACHO, N., BEKATOROU, A., FERRER, S., NIGAM, P., DROUZA, C., KOUTINAS, A.A., 2013 Saccharomyces cerevisiae and Oenococcus oeni immobilized in different layers of a cellulose/starch gel composite for simultaneous alcoholic and malolactic wine fermentations. Process Biochemistry https://doi:10.1016/j.procbio.2013.06.020

SIEVERT, D., WÜSCH, P., 1993. Amylose Chain Association Based On Differential Scanning Calorimetry. Journal of Food Science, https://doi:10.1111/j.1365-2621.1993.tb06177.x

SINGH, R., LILLARD JR., J.W., 2009. Nanoparticle-based targeted drug delivery. Experimental and Molecular Pathology https://doi:10.1016/j.yexmp.2008.12.004

SONDI, I., SALOPEK-SONDI, B., 2004. Silver nanoparticles as antimicrobial agent: a case study on E. coli as a model for Gram-negative bacteria. Journal of Colloid and Interface Science https://doi:10.1016/j.jcis.2004.02.012

SOZER, N., KOKINI, J.L., 2009. Nanotechnology and its applications in the food sector. Trends in Biotechnology, 27, 82-9. https://doi:10.1016/j.tibtech.2008.10.010

SRIUPAYO, J., SUPAPHOL, P., BLACKWELL, J., RUJIRAVANIT, R., 2005 Preparation and characterization of??-chitin whisker-reinforced chitosan nanocomposite films with or without heat treatment. Carbohydrates Polymer https://doi:10.1016/j.carbpol.2005.07.013

TENNE, R., REMSKAR, M., ENYASHIN, SEIFERT, G., 2008. Inorganic Nanotubes and Fullerene-Like Structures ( IF ). Carbon Nanotub. Advanced Topics in the Synthesis, Structure, Properties and Applications https://doi:10.1007/978-3-540-72865-8

VEJDAN, A., MAHDI, S., ADELI, A., ABDOLLAHI, M., 2016. Effect of TiO 2 nanoparticles on the physico-mechanical and ultraviolet light barrier properties of fi sh gelatin / agar bilayer fi lm. LWT - Food Science and Technology 71, 88-95. https://doi:10.1016/j.lwt.2016.03.011

WAN, Z.-L., GUO, J., YANG, X.-Q., 2015. Plant protein-based delivery systems for bioactive ingredients in foods. Food Function. https://doi:10.1039/c5fo00050e WANG, YH, WANG, J M, YANG, X. Q., GUO, J., LIN, Y., 2015. Amphiphilic zein hydrolysate as a novel nano-delivery vehicle for curcumin. Food Function. 6, 2636-2645. https://doi:10.1039/C5FO00422E

WANG, J., ZHUANG, H., HINTON, A., BOWKER, B., ZHANG, J., 2014. Photocatalytic disinfection of spoilage bacteria Pseudomonas fl uorescens and Macrococcus caseolyticus by nano-TiO 2. LWT - Food Science and Technology, 59. https://doi:10.1016/j.lwt.2014.06.062

WANG, Y., ZHANG, Q., ZHANG, C.L., LI, P., 2012. Characterisation and cooperative antimicrobial properties of chitosan/nano- $\mathrm{ZnO}$ composite nanofibrous membranes. $\quad$ Food $\quad$ Chemistry https://doi:10.1016/j.foodchem.2011.11.015

WU, G.C., ZHANG, M., WANG, Y.Q., MOTHIBE, K.J., CHEN, W.X., 2012. Production of silver carp bone powder using superfine grinding technology: Suitable production parameters and its properties. Journal of Food Engineering, https://doi:10.1016/j.jfoodeng.2011.11.013

WU, H., ZHU, S., ZENG, M., LIU, Z., DONG, S., ZHAO, Y., HUANG, H., LO, Y.M., 2014. Enhancement of non-heme iron absorption by anchovy (Engraulis japonicus) muscle protein hydrolysate involves a nanoparticle-mediated mechanism. Journal of Agriculture and Food Chemistry https://doi.org/10.1021/jf5018719

XIE WW, YIN T, ZHANG J, ZHAO SM, X.S., 2014. Effects of fish bone powder particle size on calcium bioavailability of fish bone powder-fish protein hydrolysate mixture. Chinese Journal of Food Science 35, 211-216. http://www.spkx.net.cn/EN/Y2014/V35/I7/211

XU, Y.X., REN, X., HANNA, M.A., 2006. Chitosan/clay nanocomposite film preparation and characterization. Journal of Applied Polymer Science https://doi:10.1002/App.226646 
YI, J., FAN, Y., YOKOYAMA, W., ZHANG, Y., ZHAO, L., 2016. Characterization of milk proteins-lutein complexes and the impact on lutein chemical stability. Food Chemistry,. https://doi:10.1016/j.foodchem.2016.01.035 YI, J., LI, Y., ZHONG, F., YOKOYAMA, W., 2014. The physicochemical stability and invitro bioaccessibility of beta-carotene in oil-in-water sodium $\begin{array}{lll}\text { caseinate } & \text { Food } & \text { Hydrocolloids, }\end{array}$ https://doi:10.1016/j.foodhyd.2013.07.025

YIN, T., PARK, J.W., 2014. Effects of nano-scaled fish bone on the gelation properties of Alaska pollock surimi. Food Chemistry, https://doi:10.1016/j.foodchem.2013.11.041

YIN, T., REED, Z.H., PARK, J.W., 2014. Gelling properties of surimi as affected by the particle size of fish bone. LWT - Food Science and Technology https://doi:10.1016/j.lwt.2014.03.037

ZHANG, L., SUN, Y. 2018. Poly(carboxybetaine methacrylate)-grafted silica nanoparticle: A novel carrier for enzyme immobilization. Biochemical Engineering Journal, 132, 122-129. https://doi.org/10.1016/j.bej.2018.01.013

ZHANG, H., WEI, H., CUI, Y., ZHAO, G., FENG, F., 2009. Antibacteria interactions of monolaurin with commonly used antimicrobials and food components. Journal of Food Science, https://doi:10.1111/j.17503841.2009.01300.x

ZOLFI, M., KHODAIYAN, F., 2014. Characterization of the new biodegradable WPI / clay nanocomposite films based on kefiran exopolysaccharide.Journal of Food Science and Technology, https://doi:10.1007/s13197-014-1407-6 